\title{
Addendum
}

Proceedings of The Royal Society of Queensland, 129. https://doi.org/10.53060/prsq.2021.1

\section{A New Species of Modocia (Trilobita: Ptychoparioidea) in the Late Middle Cambrian (Guzhangian: Miaolingian) Devoncourt Limestone, Northwestern Queensland}

\begin{abstract}
Peter A. Jell ${ }^{1}$
Abstract

The Tasmanian species Asthenopsis conandersoni Bentley \& Jago is recognised as closely related to Modocia priva Jell and transferred to Modocia, identifying a group of three Australian species (immodulata Öpik, conandersoni, priva) assignable to Modocia.
\end{abstract}

Keywords: trilobite, Solenopleuridae, Modocia, Lejopyge laevigata Zone.

${ }^{1}$ School of Earth Sciences, The University of Queensland, St Lucia, QLD 4072, and Queensland Museum, PO Box 3300, South Brisbane, QLD 4101, Australia (amjell@bigpond.com)

Jell, P. A. (2021). Addendum: A new species of Modocia (Trilobita: Ptychoparioidea) in the late middle Cambrian (Guzhangian: Miaolingian) Devoncourt Limestone, Northwestern Queensland. Proceedings of The Royal Society of Queensland, 129. https://doi.org/10.53060/prsq.2021.1.a

Subsequent to the immediately preceding paper (Jell, 2021) being published online, I recognised a further Australian species of Modocia. Bentley \& Jago (2014) erected Asthenopsis conandersoni Bentley \& Jago, 2014 from the Christmas Hills of northwestern Tasmania as part of a moderately diverse fauna that includes the index species Lejopyge laevigata (Dalman, 1828), plus Pianaspis sors (Öpik, 1961) and Centropleura phoenix Öpik, 1961. These species occur with Modocia priva Jell, 2021 in the Guzhangian (Lejopyge laevigata Zone) Devoncourt Limestone, northwestern Queensland (Öpik, 1961). Bentley \& Jago (2014) assigned exactly the same age to their Christmas Hills fauna with Modocia conandersoni.

Asthenopsis conandersoni Bentley \& Jago, 2014 shares with M. priva a well-rounded glabella anterior (a solenopleurid rather than ptychopariid feature, though not definitive), small palpebral lobes situated anterior to the cranidial mid-length, 12 thoracic segments and a pygidium lacking a border furrow. In concert, these features place that species with M. priva in Modocia and not Asthenopsis. Bentley \& Jago (2014) commented that their species differed from all other known species of Asthenopsis in possessing 12 thoracic segments rather than the 14 in Asthenopsis. Both Bentley \& Jago (2014) and Jell (2021) regarded Modocia? immodulata Öpik, 1967 as a related species with 12 thoracic segments and with Modocia priva Jell, 2021 also possessing 12 thoracic segments, a group of three Modocia species (Figure 1) is identified occurring within two consecutive biozones in widely separated parts of Australia. Modocia conandersoni (Bentley \& Jago, 2014) is distinct from M. priva in its longer (sag.) anterior border, more narrowly rounded glabella anterior, its thoracic fulcral line being closer to the axial furrow producing more extensive free thoracic pleurae and its lack of tuberculate ornament, particularly on the pygidial axis.

This work is licensed under a Creative Commons Attribution-NonCommercial-NoDerivatives 4.0 International Licence. Individual articles may be copied or downloaded for private, scholarly and not-for-profit use. Quotations may be extracted provided that the author and The Royal Society of Queensland are acknowledged. Queries regarding republication of papers, or parts of papers such as figures and photographs, should be addressed to the Secretary of The Royal Society of Queensland (rsocqld@gmail.com). 

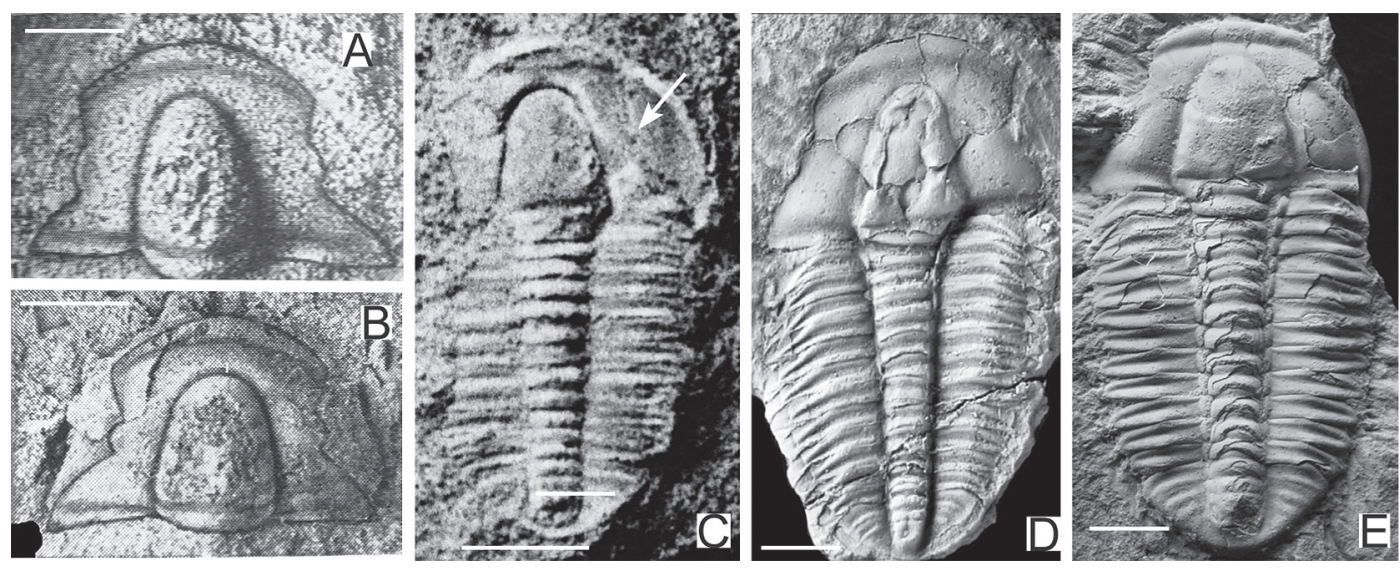

FIGURE 1. A, B, Modocia oweni (Meek \& Hayden, 1861), exfoliated internal moulds of cranidia (B retains some exoskeleton), in dorsal view; from Walcott, 1924, pl. 16, figs 1 (USNM24581) and 3 (USNM1180), respectively; B is the holotype. C, Modocia? immodulata Öpik, 1967, CPC5388, incomplete exoskeleton in dorsal view, arrow indicates indistinctly preserved palpebral lobe, from Öpik, 1967, pl. 4, fig. 9 (C) Commonwealth of Australia (Geoscience Australia) 2021, released under the Creative Commons Attribution 4.0 International Licence http://creativecommons.org/licenses/by/4.0/legalcode). D, Modocia conandersoni (Bentley \& Jago, 2014), UTGD125577, incomplete exoskeleton in dorsal view (reproduced with permission from Bentley \& Jago 2014, fig. 9G, AAP Memoir 45). E, Modocia priva Jell, 2021, QMF59832, incomplete exoskeleton in dorsal view, from Jell, 2021, fig. 1D. Scale bars $=10 \mathrm{~mm}$.

\section{Literature Cited}

Bentley, C. J., \& Jago, J. B. (2014). A Cambrian Series 3 (Guzhangian) trilobite fauna with Centropleura from Christmas Hills, northwestern Tasmania. Memoirs of the Association of Australasian Palaeontologists, 45, 267-296.

Dalman, J. W. (1828). Arseberattelse om nyare zoologiska arbeten och upptacker. Svenska Vetenskapsacademien, Arsberattelser, Stockholm.

Jell, P. A. (2021). A new species of Modocia (Trilobita: Ptychoparioidea) in the late middle Cambrian (Guzhangian: Miaolingian) Devoncourt Limestone, Northwestern Queensland. Proceedings of The Royal Society of Queensland, 129. https://doi.org/10.53060/prsq.2021.1

Meek, F. B., \& Hayden, F. V. (1861). Descriptions of new Lower Silurian (Primordial), Jurassic, Cretaceous and Tertiary fossils collected in Nebraska territory, with some remarks on the rocks from which they were obtained. Proceedings of the Academy of Natural Sciences of Philadelphia, 1861, 415-447.

Öpik, A. A. (1961). The geology and palaeontology of the headwaters of the Burke River, Queensland. Bureau of Mineral Resources Geology and Geophysics Australia Bulletin, 53, 1-249.

Öpik, A. A. (1967). The Mindyallan fauna of north-western Queensland. Bureau of Mineral Resources Geology and Geophysics Australia Bulletin, 74, 1-404.

Walcott, C. D. (1924). Cambrian and Lower Ozarkian trilobites. Smithsonian Miscellaneous Collections, $75,53-60$. 